\title{
Experience of Investment Activity in the Railway System of the Republic of Uzbekistan
}

\author{
Gaibnazarova Zumrat Talatovna, Makhkamova Mamlakat Abdukadirovna, Saitkamolov \\ Mukhammadkxuja Sobirkhuja ugli, Ziyayeva Dilorom Sayfutdinovna, Mirkhamidova Dilorom \\ Nigmatillayevna
}

\begin{abstract}
This article discusses the investment activities of the leading countries of the world. The main distinctive features of the investment activity of the railway industry in foreign countries, including China, Russia, USA, UK and Ukraine, are given. Displays the opinions of well-known experts and economists who have studied the investment activities in the railway industry for years. The experience of the investment activity of the railway industry of the Republic of Uzbekistan using the information resource of JSC «Uzbekistan Railways» has been performed. According to JSC «Uzbekistan Railways», investments in the railway industry in 2018 decreased significantly distinctive to 2017. Attracted investments should receive a technical, financial and economic justification for each project to have a financial recoupment and economic return. To this end, it is necessary to increase the volume of intensive investments and innovations implemented in the railway industry of the Republic of Uzbekistan. It should be noted that after adding coal production to the structure of railways, the responsibility of JSC «Uzbekistan Railways» to the state and the population increased several times. SWOT experiment of the activities of the railway industry of the country. In certain areas of the railway identified specific problems to solve. At the moment, some issues are not solved in the railway itself and beyond. For example, tariffs for domestic freight and passenger transportation are controlled by the Ministry of Finance, service levels mainly depend on the operation of railways in other countries, most of the problems are external and therefore difficult to solve. In this regard, it is necessary to solve the problems listed below and give even more impetus to the railway system. Having studied the problems of the industry, the conclusions and recommendations for improving the investment activity of the railways of the Republic of Uzbekistan are given.
\end{abstract}

Keywords: railway industry, railway transport, investment activity, investments, foreign experience.

\section{INTRODUCTION}

To achieve the required goals and directions in intensive investment activities, the development and implementation of appropriate intensive investment projects is necessary, for this it is necessary to develop the right strategy to stimulate investment attraction. At the heart of this strategy are specific programs to improve efficiency. Basically, when stimulating the attraction of investments, one can understand the process of creating even more favorable conditions, guarantees for the wide attraction of capital in the country's railway industry. In the modern market economy, this task has become key, and its solution requires the development of new methods and mechanisms to stimulate investors.

Revised Manuscript Received on November 15, 2019

Gaibnazarova Zumrat Talatovna, Assistant Professor, Department Of Corporate Governance, Tashkent State Technical University.

M.A. Makhkamova, Professor, Tashkent State Technical University.

M.S.Saitkamolov, Assistant and Doctoral Student, Department of Economics, Tashkent State Technical University.

D.S.Ziyayeva, Senior Teacher, Department of Corporate Governance, Tashkent State Technical University.

D.N.Mirkhamidova, Senior Teacher, Department of Corporate Governance, Tashkent State Technical University.

And this determines an objective and self-critical assessment of the work done in this area. I must admit that in recent years a lot of work has been done in Uzbekistan and a lot of legislative acts have been adopted to improve the investment climate to attract intensive investments.

\section{LITERATURE INSPECTION}

The experience of foreign scientists and experts in the railway transport system, it should be noted that investing in this direction with great interest is being studied all over the world. Based on this, we present below some conclusions of scientists on investing in the railway system of their and foreign countries.

Agafonov D.V. Studying the state regulation of railway infrastructure services, he cites the following practical facts: "The effective relationship of transport market participants is largely determined by the state method to organizing the functioning of the railway industry and railway infrastructure in particular" [Agafonov, 2017]. The article cited examples of railway regulation in two directions. This is regulation by the state and the organization of the railway to fulfill its mandatory functions. Because in the practice of developing the railway industry, the above 2 areas are interconnected.

Doctor of Economics, Ural State University of Railway Engineering Rachek S.V. in her article on foreign experience in reforming railways, experience of the UK, it came to the conclusion that "The experience of the UK has shown that privatization is a necessary condition, but not sufficient to achieve successful reform results" [Rachek, 2013]. In this regard, the liberalization of the railway industry is of great importance. Rearrangements in the railway industry did not solve the investment problem, and American companies are currently managing and regulating freight traffic on the UK railways.

Lapidus B.M. Studying the strategic development of railway transport in Russia, I came to such conclusions on the development of the industry based on the example of the USA: "The USA has a well-functioning system of interaction of neighboring roads for the promotion of goods, the use of rolling stock and mutual settlements. Every year, American railways carry $42 \%$ of all cargo - more than any other mode of transport "[Lapidusa, 2008]. Based on this, it should be noted that freight traffic through railways in the Republic of Uzbekistan at the moment is about $4-5 \%$, it is planned to increase the volume of freight traffic through railways to $80 \%$ by the country's Transport Development Strategy by 2035 . And in this it is necessary to take into account and can in some cases use the methods of development of US rail transport. 
Kozachenko D., Verlan A., Kutateladze O. famous Ukrainian experts in the railway sector, having made an studies of the industry, came to the following thoughts: "Thus, the long-term lack of investment in the industry led to the fact that the physical depreciation of fixed assets of the railway industry exceeded $80 \%$, including traction rolling stock - $94.2 \%$, freight cars - 88.2\%, track facilities $86 \%$ "[Kozachenko, Verlan, Kutateladze, 2013]. At the moment, in the Republic of Uzbekistan, the demand for freight and passenger transportation via rail is very high. But it is necessary to increase the number of cars. There are a lot of old wagons in the park. Typically, the life of a wagon is estimated at about 30 years. It should be noted that in the country, factories that repair and build cars operate at full capacity. But since the demand is high, to provide cars to everyone, they just do not have time.

Russian scientists Galiev I.I., Usmanov Yu.A. studying the experience of China in the railway system, the following thoughts on the development of the industry are noted: "Five large railway companies - industry, engineering, construction, materials, communications and signaling - are separated from transport enterprises and are given more independence. In fact, China is achieving significant development in the field of railway transport without a privatization process that would contradict the country's traditional domestic policy "[Galiev, Usmanov, 2005]. But at the moment, China plans to build or restore the "Silk Road", so to speak, because this will primarily reduce the transportation time, and secondly, the cost of transportation will decrease in relation to other types of transportation. Another need to take into account China is very much studying foreign experience to develop its own options for the development of the industry and this is helped by the desire of personnel to develop and reach new heights in the railway direction.

Having studied several works of leading experts in the development of railway transport, it is necessary to take into account economic, social and geopolitical factors that will affect the railway industry of the Republic of Uzbekistan. Since the economic situation of the country, transitions to commercial structures, the social situation of the population, political ties with neighboring countries can greatly affect the development of railway transport with our country. Therefore, in our opinion, it is possible to privatize railway facilities in part, but maintaining state control. It is possible to rent freight cars, but with subsequent redemption after a while. But you need to take into account demand in the transportation market and repayment maturities with a longer term.

\section{THEORY}

The scientific theory is formulated by the fact that at the moment it is necessary to study the railway industry of the Republic of Uzbekistan from the inside. After the studies, it will be possible to make recommendations on the development of investment activities of the industry and the country.

\section{METHODOLOGY}

The methodology for studying the country's railway system is carried out by the method of distinctive and SWOT experiment, to identify specific problems in the development of the country's industry. At present,

investment activity in Uzbekistan is very stimulated, but how it is carried out in the railway industry and mainly which areas are allocated the most investments.

\section{DATA}

Investment activity of JSC "Uzbekiston Temir Yollari" at the moment, the amount of capital investments takes into account the availability of sources of financing and financial resources of JSC "Uzbekistan Temir Yollari". Investments are made in order to ensure continuous operation of railway transport, improve the state of primary and secondary activities and increase financial profitability. Attracted investments should receive financial, technical, social and economic justification, so that each project has a sufficiently fast financial return and high economic and social return at the facilities of Uzbekiston Temir Yollari JSC. Significant funds are planned to be used to electrify the railway section in the Ferghana Valley, electrify the railway lines in Kashkadarya with the organization of high-speed passenger trains, electrify the railway line from Bukhara to Khiva, modernize Shargunkumir JSC with an increase in production capacity up to 900,000 tons of coal per year.

Table 1.

JSC "Uzbekistan Temir Yollari"

\begin{tabular}{|c|c|c|c|c|}
\hline \multirow{2}{*}{ Direction of the project } & \multicolumn{4}{|c|}{ Volume of investments by years (million dollars) } \\
\cline { 2 - 5 } & $\mathbf{2 0 1 6}$ & $\mathbf{2 0 1 7}$ & $\mathbf{2 0 1 8}$ & $\mathbf{2 0 1 9}$ \\
\hline New construction & 524,6 & 521,2 & 415,11 & 206,43 \\
\hline $\begin{array}{c}\text { Modernization and } \\
\text { reconstruction }\end{array}$ & 85,83 & 83,61 & 126,74 & 183,45 \\
\hline Other directions & 82,38 & 125,69 & 59,16 & 116,95 \\
\hline Total & $\mathbf{6 9 2 , 8 1}$ & $\mathbf{7 3 0 , 4 2}$ & $\mathbf{6 0 1 , 0 1}$ & $\mathbf{5 0 6 , 8 3}$ \\
\hline
\end{tabular}

Currently priority investment projects of JSC "Uzbekistan Temir Yollari" are:

- "Electrification of the Pap-Namangan-Andijan railway section", "Electrification of the Karshi-Kitab railway line with the organization of high-speed movement of passenger trains", "Electrification of the Bukhara-Misken-Khiva railway line", "Electrification of the Andijan-SawaiKhanabad railway section", implementation which will reduce operating costs for energy resources, repair and maintenance of technical equipment, increase the throughput of the railway line, reduce the negative impact on the environment environment.

"Construction of the second stage of the Yunusabad Tashkent metro line", "Construction of the Sergeli line of the Tashkent metro", "Construction of the ring elevated underground metro line in the city of Tashkent", the implementation of which will allow to develop the road transport infrastructure of the city of Tashkent, reduce passenger traffic by vehicles, which will improve ecological situation in the city.

- "Construction of the Urgench-Khiva railway line", the implementation of which will expand the tourist potential of the territories and create a single tourist route that includes the historical cities of the republic - Samarkand, Bukhara, Khiva, as well as providing favorable conditions for further integrated economic and social development of the Khorezm region.

- construction of the Angrenskaya and Nishbash mines, the modernization of Shargunkumir JSC, the modernization of the railway sector and the maintenance of the production capacity of Uzbekugol JSC, the implementation of which will increase the production of hard and brown coal in the 
country, using a modern mechanized treatment plant. train traffic, reduce operating costs and improve the quality of services

-construction, acquisition, modernization and restoration of rolling stock, contributing to the renewal and improvement of the fleet of the rolling stock of the company, reducing operating costs, ensuring the safety of train traffic and improving the quality of the services provided [Official website of Uzbekistan Temir Yollari, http://railway.uz / ru / proekty / 1920 /].

\section{EMPIRICAL RESULTS}

\begin{tabular}{|c|c|}
\hline \multicolumn{2}{|c|}{ Local railway network } \\
\hline Strengths & Weaknesses \\
\hline $\begin{array}{l}\text { 1. Reserve power in the system. } \\
\text { 2. Good network coverage. } \\
\text { 3. Experienced management }\end{array}$ & $\begin{array}{l}\text { 1. Loss of synergy due to the } \\
\text { fragmentation of the Central Asian } \\
\text { Railways and the competitive } \\
\text { development of new lines. }\end{array}$ \\
\hline Opportunities & Threat \\
\hline $\begin{array}{l}\text { 1. Improving the efficiency of operations } \\
\text { through investment on new roads in the } \\
\text { region. }\end{array}$ & $\begin{array}{l}\text { 1. A sharp increase in prices for major } \\
\text { imported materials and spare parts }\end{array}$ \\
\hline
\end{tabular}

\section{International railway corridors} network of the CIS countries. 2. The network of corridors is becoming countries, which caused problems after more integrated in Uzbekistan, thereby independence.

reducing costs and delays when crossing 2 . Infrastructure problems and borders.

3. Improving the infrastructure of inland rail transport will have a positive effect on international corridors. Opportunities restrictions in neighboring countries.

3. The need to change gauges to reach key markets.

1. The Angren-Pap line should attract international transit traffic. the Kyrgyz Republic will generate transit / international traffic.

1. Depreciation of infrastructure in the networks of neighboring countries, leading to even greater speed limits.

2. Lack of financing for the construction of railways lines from Kyrgyzstan to -rehabilitation of railways, which will ensure the safety of

\begin{tabular}{|c|c|}
\hline Strengths & Weaknesses \\
\hline 1. Access to the extensive railway & 1. The CIS railway network is \\
\hline
\end{tabular}

2. Communication with China through

\begin{tabular}{|c|c|}
\hline $\begin{array}{l}\text { value goods. } \\
\text { 3. Car tracking system to determine the } \\
\text { location of goods at any time. } \\
\text { 4. UTY is an experienced operator. }\end{array}$ & \\
\hline Opportunities & Threat \\
\hline $\begin{array}{l}\text { 1. The growth of trade relations with } \\
\text { China and East Asia favors rail transport. } \\
\text { 2. Potential growth in Afghanistan as an } \\
\text { export / transit market. } \\
\text { 3. The potential of intermodal services } \\
\text { for servicing value-added transport. }\end{array}$ & $\begin{array}{l}\text { 1. The increase in transportation carried } \\
\text { out at a high tariff due to raw materials. } \\
\text { 2. Lack of investment in the CIS railway } \\
\text { system, leading to a longer, less reliable } \\
\text { transportation time. }\end{array}$ \\
\hline
\end{tabular}

for servicing value-added transport.

\section{Intermodal Services}

\begin{tabular}{|c|c|}
\hline Strengths & Weaknesses \\
\hline $\begin{array}{l}\text { 1. Lower transportation costs on major } \\
\text { routes distinctive to road transport. } \\
\text { 2. Distinctively transportation time if } \\
\text { block trains are implemented. } \\
\text { 3. Significant potential for expansion. } \\
\text { 4. Reduces congestion at automobile } \\
\text { border crossings }\end{array}$ & $\begin{array}{l}\text { 1. Problems with service and reliability } \\
\text { make intermodal transport less attractive } \\
\text { than automobile if cost is not the main } \\
\text { issue. } \\
\text { 2. Most of the problems are external, } \\
\text { and therefore difficult to resolve. } \\
\text { 3. Lack of use of through and combined } \\
\text { bills of lading. } \\
\text { 4. The unimodal nature of the freight } \\
\text { forwarding industry. }\end{array}$ \\
\hline Opportunities & $\begin{array}{l}\text { Threat } \\
\end{array}$ \\
\hline $\begin{array}{l}\text { 1. The development of door-to-door } \\
\text { services, thereby reducing overall } \\
\text { transportation costs. } \\
\text { 2. Financial incentives for developing } \\
\text { Uzbek producers of exported goods. }\end{array}$ & $\begin{array}{l}\text { 1. Shipping companies, freight } \\
\text { forwarders and railways do not support } \\
\text { the concept. } \\
\text { 2. Too many objects without the } \\
\text { necessary critical mass to ensure } \\
\text { viability. }\end{array}$ \\
\hline
\end{tabular}

\section{CONCLUSION}

After studying the investment activity and making a SWOT experiment of the industry, we came to the following conclusions:

- The CIS railway network is designed to serve the needs of neighboring countries, which causes problems after the independence of our country. China due to the high cost of the project.

\section{Inland Rail}

\begin{tabular}{|c|c|}
\hline Strengths & Weaknesses \\
\hline $\begin{array}{l}\text { 1. Reserve capacities for } \\
\text { transportation. }\end{array}$ & $\begin{array}{l}\text { 1. Tariffs for domestic freight transport } \\
\text { are controlled by the Ministry of }\end{array}$ \\
\hline $\begin{array}{l}\text { 2. Good communication with large } \\
\text { shippers and consignees } \\
\text { 3. The opening of the Tashguzar- }\end{array}$ & $\begin{array}{l}\text { Finance. } \\
2 . \quad \text { Wagon economy needs } \\
\text { modernization. }\end{array}$ \\
\hline
\end{tabular}

B. The opening of the Tashguzar-
Boysun-Kumkurgan line improved the

competitive position of the Tashkent-

Termez corridor.

\begin{tabular}{|c|c|}
\hline Opportunities & Threat \\
\hline 1. Convenient location for the & 1. Increasing domestic competition from
\end{tabular}
devention

2. Large investments in the construction of new lines in the region will increase the freight rail market. the trucking industry.

2. The road reconstruction program will improve road transport.

3. The development of local trucking companies and the renewal of the fleet of vehicles will increase competition.

\section{Passenger Rail}

\begin{tabular}{|c|c|}
\hline Strengths & Weaknesses \\
\hline $\begin{array}{l}\text { 1. Defined reserve capacity for new } \\
\text { services. } \\
\text { 2. Good coverage in the regions of the } \\
\text { republic. }\end{array}$ & $\begin{array}{l}\text { 1. Tariffs for domestic passenger } \\
\text { transportation are controlled by the } \\
\text { Ministry of Finance. } \\
\text { 2. Wagon economy needs } \\
\text { modernization. } \\
\text { 3. The limited concentration of } \\
\text { marketing survey. }\end{array}$ \\
\hline Opportunities & Threat \\
\hline $\begin{array}{l}\text { 1. Conclusion of agreements with } \\
\text { tourism organizations. }\end{array}$ & $\begin{array}{l}\text { 1. Loss of passenger traffic in favor of } \\
\text { private transport / air transportation } \\
\text { services. } \\
\text { 2. The program for the reconstruction of } \\
\text { roads and rolling stock will improve the } \\
\text { implementation of intercity bus transport. }\end{array}$ \\
\hline
\end{tabular}

International freight rail transport

\begin{tabular}{|l|l|}
\hline \multicolumn{3}{|c|}{ Strengths } & \multicolumn{1}{|c|}{ Weaknesses } \\
\hline $\begin{array}{l}\text { 1. Access to an extensive railway } \\
\text { network throughout the CIS. }\end{array}$ & $\begin{array}{l}\text { 1. Unsatisfactory service levels for } \\
\text { value-added transport. } \\
\text { 2. High competitiveness when } \\
\text { 2. Service levels mainly depend on the } \\
\text { transporting over long distances, } \\
\text { especially for the transportation of low- }\end{array}$ \\
\hline
\end{tabular}

- Problems with the uneven distribution of transport infrastructure in different regions of the country.

- The need for a gauge change that limits the achievement of external, more attractive and developed markets.

- Levels of service are very much dependent on the activities of railways in other countries, which, with a change in the management structure and activities, must be resolved again.

Service and reliability issues make intermodal transport less attractive and difficult to access if the cost of transporting goods is not a major issue.

- Most of the problems are external, so some of them are difficult to solve.

- Lack of use of through and combined bills of lading.

- The unimodal nature of the freight forwarding industry limits the accelerated development of industry infrastructure.

- Lack of multimodal transportation of passengers and cargo.

To solve the above problems, we will give several recommendations:

- Improving the efficiency of functioning due to intensive investments in the electrification of roads in the Republic of Uzbekistan.

- The growth of trade relations with China and East Asia favors rail transport and an increase in the flow of foreign investment in the country and in the railway industry.

- The conclusion of contracts with tourism organizations will lead to an additional stream of nailed.

- Potential growth in Afghanistan as a new railway market and passenger turnover.

- The potential of intermodal services for transportation 
services and the ecology of the country.

The development of door-to-door services, thereby reducing overall transportation costs for the transport of goods.

- Financial incentives for developing Uzbek producers of exported goods.

- Creation of new multimodal transportation to increase the volume of cargo and passenger traffic.

\section{REFERENCES}

1. Agafonov D.V. (2017). State regulation of railway infrastructure services in the context of the structural transformation of the industry // Internet magazine «SCIENCE». Vol. 9, No. 2. pp. 1-16. Article URL: http://naukovedenie.ru/PDF/16EVN217.pdf

2. Agafonov D.V. (2017). Studies of the feasibility of separating the railway infrastructure of high-speed highways in the Russian Federation // Internet magazine «SCIENCE». Vol. 9, No. 1. pp. 1-11. Article URL: http://naukovedenie.ru/PDF/20EVN117.pdf

3. Vinokurov E.Yu., Lobyrev VG, Tikhomirov A.A., Tsukarev T.V. (2018). Silk Road Transport Corridors: Barriers Studies and Investment Directions - St Petersburg: EDB Center.

4. Galiev I.I., Usmanov Yu.A. (2005).The development of railway transport in Russia in a market economy. Omsk. OmGUPS.

5. Gaibnazarova Z.T. (2016). Development of HR for expansion of employment possibilities in Uzbekistan // Scientific and analytical journal Science and Practice of the Plekhanov Russian University of Economics. № 4 (24). pp. 57-63.

6. Gaibnazarova Z.T. (2017). Improving the System of Higher Education is the Main Factor in the Formation of Human Capital // Scientific and analytical journa Science and Practice of the Plekhanov Russian University of Economics. № 3 (27) pp. 72-78.

7. Gaibnazarova Z.T. (2018). Prospects for the development of touristic potential of Uzbekistan // Scientific Survey of Faculty of Economics. Electronic Journal. Vol. 10. № 1 (27). pp. 94-104

8. Gaibnazarova Z.T. (2018). Improving the Quality of Education in Universities of Uzbekistan: the Experience of the Tashkent State University // Scientific and analytical journal Science and Practice of the Plekhanov Russian University of Economics. № 3 (31). pp. 90-98.

9. Kozachenko D., Verlan A., Kutateladze O. (2013).Problems and prospects of reforming railway transport in Ukraine // Ports of Ukraine. №8 (130). p 1.

10. Lapidus B.M. (2008). Strategic development of railway transport in Russia / ed. M.: MCFER.

11. Nikulina S.I. (2014).The experience of attracting foreign investment in the PRC / Financial journal. № 3. pp. 167-175.

12. Borisoglebskaya L.N., Chetverikova V.M. (2013). Part II. / Ed. Liu Juan, Yang Chengyuy. Development of the BRICS countries in the global space: monograph. M.: INFRA-M.

13. Rachek S.V. (2013). Foreign experience of reforming railways // News of USEU. Vol. 6 (50). p 62.

14. Rakhimjonov B.R. (2013). Some aspects of investment management in railway transport // Internet magazine «SCIENCE». №1. pp. 1-4.

15. Reutov E.V. (2018). The experience of reforming railways in the CIS countries and Eastern Europe. pp. 1-37.

16. Suyunchev M.M., Mozgovaya O.O., Agafonov D.V. (2016). The development of mechanisms of state regulation, creating conditions for attracting and protecting investments in infrastructure sectors (for example, rail transport) // M. pp. 42-43.

17. Mozgovaya O.O., Agafonov D.V. (2015). The directions of enhancement of state regulation machineries for the purpose of attraction and protection of investments into infrastructure of a rail transport // Infrastructure industries of economy: problems and prospects of development: the collection of materials $\mathrm{X}$ of the International scientific and practical conference. pp. 145-153

18. Business plan of the State Joint Stock Railway Company Uzbekistan Temir Yullari for 2015 .

19. State Program for the Development of the Transport Complex of the Republic of Belarus for 2016-2020.

20. Official website of Uzbekistan Temir Yullari, http://railway.uz/ru/proekty/1920/

21. Railway Reform: A Compendium of Materials for Improving the Efficiency of the Railway Sector. Second edition. September 2017. pp. 527-552.

22. Transport strategy of the Russian Federation for the period up to 2030 (http://government.ru/media/files/41d4e8c21a5c70008ae9.pdf).

23. Statistics of FDI in China in January-May 2014 [Electronic resource] / Official website of the Ministry of Commerce of the PRC. - Access mode: http://english.mofcom.gov.cn/article/statistic/foreigninvestment/201407/20140700 665318.html.

24. World Investment Report 2014. Investing in the SDGs: an Action Plan [Electronic resource] / Official website of the United Nations Conference on Trade and Development (UNCTAD). - Access mode: http://unctad.org/en/ Publications Library / wir2014_en.pdf.

\section{AUTHORS PROFILE}

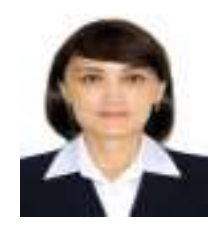

First Author. Gaibnazarova Zumrat Talatovna, higher education, in 2002 graduated Tashkent State Technical University with a degree in Management. In 2004 she graduated master degree of this university in a specialty Innovation Management. In 2004, she entered to post graduate school at the Tashkent State Technical University. Having successfully graduated of graduate school, she defended her thesis on the topic "Theoretical Foundations of Increasing the Effectiveness of Innovative Investment" and in 2012 she received a Ph.D. in Economical theory and in 2017 received the title of Associate Professor. From August 2018 to the present, she works as an assistant professor at the Department of Corporate Governance. During the labor activity of Gaibnazarova Z.T. published 1 textbook, 4 study guides, 1 monograph, published more than 60 scientific articles and abstracts at international, republican and university scientific and methodological, scientific and practical conferences. Under the leadership of Gaibnazarova Z.T. trained more than 14 highly qualified bachelors and 2 masters. The final qualification works and the candidate dissertations performed by them are aimed at solving various economic problems of industrial enterprises of the Republic of Uzbekistan. She is engaged in scientific research on the topic "The impact of human capital on improving the efficiency of industrial production in the context of modernization and diversification of the economy". Gaibnazarova Z.T. since 2017, has been a corresponding member of the International Academy of National Economy and Economics, and also conducts her activities as a member of the editorial board of the Russian Journal of Social and Labor Research. Gaibnazarova Z.T. was a member of the executive group of the international project 530326-TEMPUS-1-2012-1-IT-TEMPUS-SMGR on the theme "QUEECA - The quality of engineering education in Central Asia", designed for 2012 2015, within the framework of the European Union's TEMPUS program, and was also a member of the executive group of basic research - economic contract No. $1 / 14$ of Uzgeoburneftegaz company on the theme "Development and implementation of drilling fluid compositions based on modified starch of local production" in the period 2014-2016.

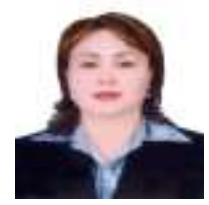

Second Author. M.A. Makhkamova since 2004 work at the Tashkent State Technical University. She defended her doctoral thesis at the Specialized Council on "Effective formation of organizational and economic mechanism for managing innovation activity in industrial enterprises of the Republic of Uzbekistan". Professor since 2008. She is the author of more than 200 scientific works - monographs, textbooks, educational and methodica manuals, scientific articles during her scientific and pedagogical activity. Her articles have been published in Germany, Korea, Russia, Indonesia Iran, Kazakhstan and other countries. She created a scientific school on the problems of effective development and management of innovation processes in industrial enterprises in the Republic.

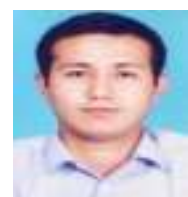

Third Author. M.S.Saitkamolov in 2016 graduated the Tashkent Financial Institute, Master's degree in Management. He is an assistant and doctoral student of the Department of Economics of the Tashkent State Technical University. He is the author of more than 30 scientific works - methodical manuals, scientific articles during his scientific and pedagogical activity. His articles have been published in Russia, Hungary and other countries. He is currently writing a thesis on "Ways to improve the efficiency of investment activity in the railway system of the Republic of Uzbekistan".

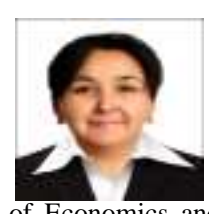

Fourth Author. D.S.Ziyayeva start her work from September 2017 on the faculty Engineering Technology of Tashkent State Technical University in a position Senior Teacher on the Department of Corporate Governance. In 1989 she graduated the Tashkent Institute of National Economy the specialty of Economics and Mathematics. Scientific direction Implementation and improvement of corporate governance in joint-stock companies. Her articles have been published in Germany, Russia, USA and other countries.

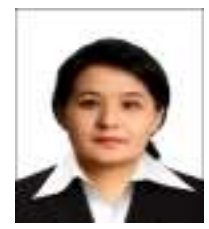

Fifth Author D.N.Mirkhamidova from December 2017 sterted her work on the faculty Engineering Technology of Tashkent State Technical University on the position Senior Teacher, Department of Corporate Governance. In 1999 she graduated the Tashkent Road Institute on the specialty of "Organization and management of road transport", economist-engineer. Scientific direction Introduction of theoretical and methodological bases of corporate governance in the Republic of Uzbekistan and increase of efficiency of management organizations. Her articles have been published in India, Russia and other countries. 